\title{
INTERAKSI HORMON DAN EPILEPSI
}

\author{
HORMONE AND EPILEPSY INTERACTION \\ Ahmad Sulaiman Alwahdy, * Astri Budikayanti, * Fitri Octaviana, * Donny Hamid**
}

\section{ABSTRACT}

Hormones are signaling chemical molecules between cells that circulated in blood within the human body and play important roles for human being. Unfortunately, not all their functions are known, especially in epilepsy. Studies reported interactions between hormones and epilepsy, also with antiepileptic drugs (AEDs). For example, seizures may be induced by estrogen, while AEDs can decrease hormone level by inducing enzyme in P450 cytochrome and accelerating hormone clearance. These conditions are known as tridirectional interactions. Understanding the interactions between hormones, epilepsy and AEDs would raise an awareness and insight for clinicians especially neurologist for basic knowledges as considerations in treating patients with epilepsy.

Keyword: Antiepileptic drugs, epilepsy, hormone, seizure

\section{ABSTRAK}

Hormon merupakan molekul pembawa pesan kimiawi antar sel yang berada dalam tubuh manusia, beredar di dalam darah dan sangat penting bagi kehidupan manusia. Perannya pada epilepsi belum seluruhnya diketahui, akan tetapi berbagai penelitian yang ada menunjukan adanya interaksi antara hormon dan epilepsi begitu juga terhadap obat antiepilepsi (OAE). Sebagai contoh, bangkitan epilepsi dapat dicetuskan oleh estrogen, namun beberapa OAE yang merupakan penginduksi enzim sitokrom P450 di hati, dapat menurunkan kadar hormon di dalam tubuh dan juga mempercepat pembersihan hormon terutama hormon steroid seks. Hubungan ketiga faktor ini menciptakan hubungan yang disebut hubungan tridireksional. Dengan memahami mengenai interaksi yang terjadi antara hormon, epilepsi dan OAE, diharapkan dapat membuka wawasan bagi neurologis untuk memiliki pengetahuan dasar sebagai pertimbangan dalam tata laksana pasien epilepsi.

Kata kunci: Bangkitan, epilepsi, hormon, obat antiepilepsi

*Departemen Neurologi FK Universitas Indonesia/RSUPN Dr. Cipto Mangunkusumo, Jakarta; **SMF Neurologi RSUD Pasar Rebo, Jakarta. Korespondensi: ule842002@yahoo.com.

\section{PENDAHULUAN}

Dalam memahami bangkitan pada epilepsi, banyak faktor yang harus dipertimbangkan, begitu juga pada tatalaksananya. Keterlibatan hormon pada epilepsi tidak dapat dilupakan, terutama pada obat anti epilepsi (OAE) yang berinteraksi dengan hormon. Banyak teori dan penelitian yang melaporkan interaksi antara hormon, epilepsi, dan OAE. Interaksi di antara ketiganya menciptakan suatu hubungan yang saling memengaruhi satu sama lain. ${ }^{1}$

Kini telah banyak penelitian yang mencoba mengatasi permasalahan bangkitan dan epilepsi baik dengan modifikasi epigenetik atau melalui pendekatan terhadap fungsi hormon. Interaksi hormon yang diketahui dan telah banyak diteliti perannya terhadap epilepsi adalah hormon estrogen dan progesteron yang dihasilkan oleh ovarium, serta testosteron yang dihasilkan oleh testis. Di samping itu, akhir-akhir ini hormon tiroid, yang merupakan hormon penting dalam meregulasi ekspresi gen, diketahui juga memiliki peran dalam epilepsi.

\section{PEMBAHASAN}

\section{Hormon Steroid Seks}

Hormon steroid seks berperan dalam memengaruhi eksitabilitas saraf-saraf di otak, baik pada perempuan maupun laki-laki. Pada perempuan, terdapat dua hormon steroid seks yang berperan yaitu progesteron dan estrogen. Kedua hormon ini berfluktuasi setiap bulannya. Progesteron diketahui memiliki kemampuan sebagai antikejang, sedangkan estrogen sebagai hormon yang dapat mencetuskan terjadinya kejang. ${ }^{2,4}$ Hormon testosteron pada laki-laki dilaporkan sebagai antikejang, tetapi beberapa penelitian melaporkan efek

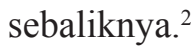

\section{Estrogen}

Terdapat tiga bentuk hormon estrogen biologis yang aktif. Estrogen utama yang dimiliki perempuan pada masa reproduktif adalah estradiol yang dihasilkan dari stimulasi hormon perangsang folikel. ${ }^{1}$ Bentuk kedua adalah estriol yang lebih banyak dimiliki pada saat kehamilan, sedangkan bentuk ketiga, yaitu estron, lebih banyak pada masa pascamenopause. ${ }^{2}$ 
Mekanisme estrogen dalam memengaruhi bangkitan epilepsi sangat kompleks. Mekanisme utama yang dilaporkan adalah efek estrogen yang dapat memengaruhi respons neuron terhadap glutamat. ${ }^{2}$ Glutamat bekerja mengaktifkan reseptor n-methyl $d$-aspartate (NMDA) maupun non-NMDA, yaitu a-amino-3-hydroxy-5-methyl-4-isoxazile proprionic acid (AMPA) dan kainat, yang bertanggung jawab dalam percepatan transmisi antar sinaps neuron di otak yang bersifat eksitatorik. ${ }^{5}$ Efek estradiol dilaporkan memiliki efek yang potensial pada transmisi eksitasi antar sinaps neuron melalui reseptor NMDA maupun non-NMDA. Efek estradiol terhadap transmisi eksitasi telah dibuktikan melalui percobaan terhadap hewan coba yang mengalami bangkitan epileptik saat diberikan estradiol pada korteksnya. ${ }^{6-7}$

Efek estradiol terhadap gamma amino butyric acid (GABA) dilaporkan tidak terlalu berpengaruh. Hal yang sama juga didukung oleh penelitian Smith dkk, yaitu tidak ditemukannya efek estradiol terhadap aktivitas inhibisi GABA pada sel purkinje di serebelum hewan coba. ${ }^{5}$ Selanjutnya, pada penelitian dengan hewan coba yang sehat, setelah pemberian estradiol, tidak ditemukan adanya aktivitas elektrik neuron di daerah korteks. Woolley dkk melaporkan efek estradiol dapat menekan inhibisi GABAdi neuron hipokampus dan merubah struktur serta fungsi pada sinaps eksitatorik pada jangka panjang. ${ }^{8}$ Perubahan struktur ini telah banyak dipelajari, terutama di daerah hipokampus yang sering menjadi tempat inisiasi dan propagasi terjadinya bangkitan epilepsi. Estradiol juga dapat meningkatkan densitas dan jumlah spinal dendrit yang menyebabkan peningkatan sinkronisasi sinaps-sinaps, sehingga terjadi cetusan di daerah hipokampus. ${ }^{6}$ Secara teori, suatu lesi fokal yang memengaruhi permeabilitas sawar darah otak (SDO) diperlukan untuk menghasilkan aktivitas epileptogenik. ${ }^{2}$ Oleh karena itu, diperkirakan pasien dengan epilepsi fokal yang menyebabkan gangguan pada SDO akan lebih rentan terhadap efek estradiol. ${ }^{2}$

\section{Progesteron}

Progesteron menghasilkan efek yang bermacam-macam setelah diubah menjadi bentuk steroid neuroaktif, yaitu $3 \alpha, 5 \alpha$-tetrahydroprogesterone $(3 \alpha, 5 \alpha-$
THP) dan allopregnanolon. Efek steroid neuroaktif terjadi melalui mekanisme yang melibatkan reseptor di nukleus dan nonnukleus. Reseptor progesteron terdistribusi cukup luas di daerah otak. ${ }^{2}$ Steroid neuroaktif 3 $3,5 \alpha$-THP akan memodulasi reseptor GABA-A yang memediasi inhibisi di otak. ${ }^{6}$ Sementara itu, pada sel purkinje di serebelum hewan coba, $3 \alpha, 5 \alpha$-THP dilaporkan menurunkan respons terhadap glutamat. Dalam jangka panjang, progesteron dapat merubah struktur dendrit, meskipun belum diketahui secara pasti. ${ }^{2}$

Jumlah steroid neuroaktif ini di dalam sirkulasi sebanding dengan jumlah progesteron, baik pada fase luteal maupun kehamilan. ${ }^{6}$ Pada saat siklus menstruasi, jumlah steroid neuroaktif ini meningkat selama 10-12 hari sebelum akhirnya menurun pada level terendah. Oleh sebab itu, pada tata laksana epilepsi katamenial sangat penting diperhatikan tidak hanya efek yang akut, tetapi juga efek jangka panjang pemberian progesteron dan efek withdrawal yang terjadi pada fungsi reseptor GABA-A. Salah satu efek withdrawal yang terjadi adalah eksitasi seperti kegelisahan, kecemasan dan bangkitan epilepsi yang dapat meningkat. ${ }^{6}$

Hubungan antara kehamilan dan peningkatan bangkitan epilepsi tidak dimengerti secara pasti. Hal ini dikarenakan perubahan yang terjadi selama kehamilan bukan hanya sebatas pada aspek hormonal saja, melainkan lebih bersifat multifaktor. Sebagai contoh, pada perempuan hamil terjadi perubahan juga perubahan fisiologi. Selain itu, terdapat perubahan farmakokinetik OAE pada perempuan hamil yang dapat menyebabkan efektifitas OAE berkurang. ${ }^{9}$

\section{Testosteron}

Efek utama dari testosteron adalah sebagai antikonvulsan, namun pada beberapa kasus dapat menjadi sebaliknya. Penyebab dualisme efek testosteron ini adalah testosteron dapat dimetabolisme menjadi 7b-estradiol yang merupakan prokonvulsan, atau menjadi androstandediol dan dihidrotestosteron yang bersifat antikonvulsan. ${ }^{2}$

Penelitian lain melaporkan bahwa androgen diketahui dapat merubah struktur dan fungsi neuron. Pada percobaan dengan menggunakan hewan coba yang 
dilakukan gonadektomi dan diberikan testosteron, didapatkan perubahan densitas dendrit di area hipokampus dan peningkatan jumlah sinaps pada area cornu ammonis (CA1). Penelitian sebelumnya menyatakan kadar fisiologis dari testosteron sangat dipengaruhi oleh sel piramidal dan sinaps-sinaps yang ada pada hipokampus di area CA1. Selain itu, area CA1 diketahui memiliki banyak reseptor androgen, sehingga banyak penelitian yang mengevaluasi area tersebut untuk melihat hubungan bangkitan epilepsi dengan kadar hormon. ${ }^{10-11}$ Meskipun demikian, perubahan morfologi neuron yang terjadi karena efek androgen pada epilepsi dan hubungannya dengan epilepsi masih belum diketahui secara pasti.

\section{Hormon Tiroid}

Hormon tiroid merupakan hormon yang berfungsi penting dalam regulasi ekspresi gen. Pada penyakit epilepsi juga telah banyak diketahui bahwa kelainan genetik merupakan salah satu penyebab epilepsi. Oleh karena fungsi yang dimiliki hormon ini, maka timbul beberapa hipotesis tentang peran hormon tiroid pada epilepsi. ${ }^{12}$

Hormon tiroid adalah hormon yang terdiri dari tirosin dan disintesis di kelenjar tiroid yang pelepasannya diatur melalui aksis hipotalamus-pituitaritiroid. Prohormontiroksin (T4) merupakan bentuk yang lebih banyak dilepaskan oleh kelenjar tiroid. Jika T4 mengalami deionisasi, maka terbentuklah bentuk yang lebih aktif, yaitu triodotironin (T3). ${ }^{12}$

Hipotesis pertama timbul dikarenakan fungsi hormon tiroid diketahui berperan dalam neurogenesis, yang meliputi migrasi, diferensiasi, mielinisasi, dan pembentukan sinaps. ${ }^{13}$ Fungsi-fungsi tersebut dimediasi oleh beberapa faktor neurotropik, antara lain fibroblast growth factor-2 (FGF-2), brain derived neurotrophic factor (BDNF), neurotrophin-3 (NT-3), nerve growth factor (NGF), glial cell line derived neurotrophic factor (GDNF), dan vascular endothelial growth factor (VEGF). Faktor-faktor tersebut berfungsi juga sebagai neuroprotektan pada sel otak yang rusak disebabkan salah satunya oleh bangkitan epilepsi. ${ }^{13}$

Hipotesis berikutnya timbul dikarenakan fungsi dari hormon tiroid sangat berperan penting pada pembentukan awal sel bukan hanya neurogenesis seperti yang disebutkan sebelumnya bahkan hormon tiroid dapat bekerja secara tidak langsung terhadap gen maupun bekerja langsung terhadap fungsi dan biogenesis mitokondria, dimana jika terdapat penurunan jumlah tiroid maka biogenesis dan fungsi dari mitokondria pada manusia akan terganggu. ${ }^{12}$ Kadar tiroid yang tidak seimbang dan tidak diperbaiki saat di kandungan maupun pada masa awal kehidupan dapat menyebabkan kelainan neurologi, seperti gangguan pada perkembangan otak dan kerusakan fungsi motorik yang permanen. ${ }^{14-15}$

Berdasarkan fungsi tiroid yang diketahui dapat memengaruhi mitokondria, banyak penelitian yang menunjukan bahwa disfungsi mitokondria, stres oksidatif, dan pembentukan radikal bebas memegang peranan penting dalam generator bangkitan epilepsi dan epileptogenesis. Pada pasien dengan epilepsi lobus temporal dilaporkan bahwa pada fokus kejang didapatkan kompleks mitokondrial yang berkurang, begitu juga pada hewan coba dengan status epileptikus dimana aktivitas kompleks mitokondrial di hipokampus berkurang. Kerusakan metabolisme mitokondria menyebabkan deregulasi siklus glutamatglutamin-GABA sehingga peranan hormon tirod menjadi penting. ${ }^{12}$

Pada penelitian yang dilakukan oleh Peternel dkk dilaporkan stres oksidatif dan pembentukan radikal bebas sangat berperan sebagai generator kejang. Jika melihat inti DNA memiliki proteksi histon, namun tidak pada DNA mitokondria yang tidak memiliki proteksi sehingga menjadi target dalam stres oksidatif dan kerusakan mitokondria DNA tersebut dapat menghambat ekspresi-ekspresi dari polipeptida yang penting.

Hipotesis berikutnya adalah dimana terdapat laporan mengenai adanya fungsi GABA yang dapat memodulasi fungsi hormon tiroid, yang diketahui pada epilepsi, GABA dapat menghambat kejang melalui peranya sebagai neurotransmisi inhibitor. ${ }^{12}$ Interaksi hormon tiroid dengan GABA bukan melalui mekanisme jalur genetik, namun lebih kepada efek langsung T3 dalam merangsang pelepasan GABA dengan meningkatkan pengambilan kalsium oleh sinaptosome. ${ }^{12}$ 


\section{Efek Bangkitan Epilepsi terhadap Hormon}

Bangkitan epilepsi berhubungan dengan kondisi hormon. Hal ini dapat terlihat pada pasien epilepsi sering mengalami gangguan hormon, antara lain yang terkait dengan reproduksi, siklus menstruasi, sindrom polikistik ovarium, dan berkurangnya potensi sperma. Secara klinis, penyebab permasalahan hormonal ini sangat sulit ditentukan apakah efek langsung dari bangkitan epilepsi atau faktor lain, misalnya pengaruh psikososial, penggunaan OAE, dan komorbid lainnya. ${ }^{1-2}$

Penelitian oleh Danielle A dkk menunjukkan disfungsi seksual lebih sering terjadi pada pasien epilepsi lobus temporal kanan daripada kiri. ${ }^{16}$ Selain dan sekresi luteinizing hormone-releasing hormone (LHRH). Pada area hipotalamus, nukleus yang terlibat dalam fungsi endokrin reproduksi adalah nukleus preoptik medial (MPO), bagian ventrolateral dari hipotalamus ventromedial (VMHvL), dan nukleus ventral premamilari (PMV). Adapun area preoptik lateral (LPO), area preoptik medial (MPA), bagian dorsomedial dari hipotalamus ventromedial (VMHdm), dan nukleus paraventrikel hipotalamus (PVH) merupakan area yang fungsinya tidak dominan terhadap reproduksi. Aktivasi asimetris disebabkan oleh bangkitan epilepsi baik di sisi hemifer kiri maupun kanan yang menghasilkan efek berbeda terhadap fungsi endokrin reproduksi. ${ }^{19}$

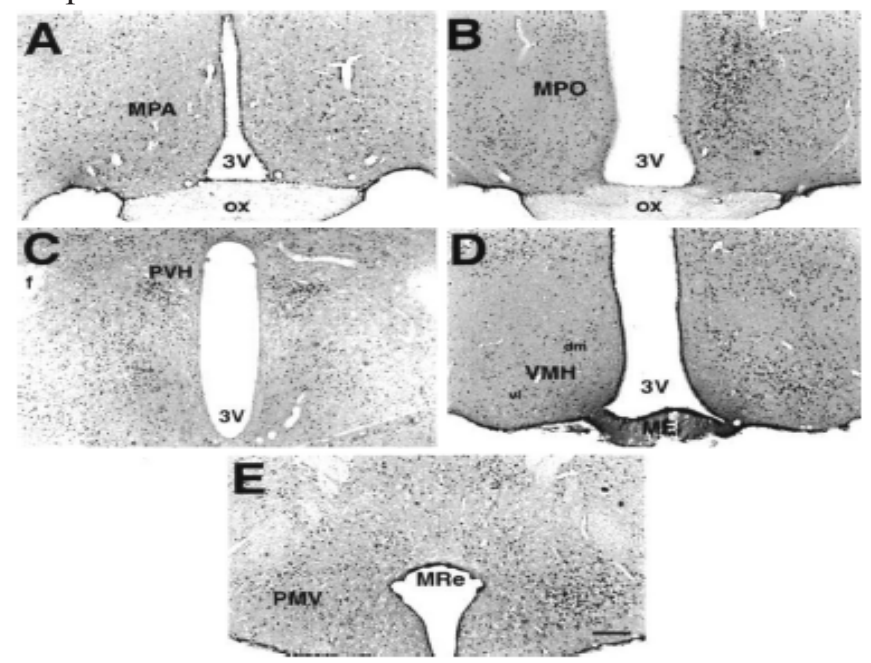

Gambar 1. Fotomikrograf Nukleus Hipotalamus

Pada hewan coba yang dilakukan stimulasi kejang pada amigdala kanan. Evaluasi dilakukan dengan membandingkan jumah neuron teraktivasi pada sisi kiri dan kanan yang mengekspresikan protein Fos (Fos-ir). A,C: Terdapat jumlah neuron Fos-ir yang sama disisi kiri dan kanan dari medial preoptik (MPA) dan nukleus paraventrikel hipotalamus (PVH). Terdapat perbedaan jumlah neuron Fos-ir di area yang berbeda. B,D,E: Peningkatan jumlah terjadi pada area MPO, VMHVL dan PMV yang terlibat dalam fungsi endokrin reproduksi. Nukleus preoptik medial (MPO), ventrolateral dari ventromedial hipotalamus (VMHvL), premamilari nukleus ventral (PMV), area lateral preoptik (LPO), nukleus ventromedial dari dorsomedial hipotalamus (VMHDM), gambar sudah mendapatkan izin untuk ditampilkan. ${ }^{19}$

itu,pasien epilepsi lobus temporal kanan memiliki angka prolaktin yang lebih tinggi dan sangat berkontribusi terhadap penurunan libido serta kesulitan ereksi. ${ }^{17-18}$

Tahun 2003, Hergoz dkk melaporkan pada epilepsi lobus temporal sisi kiri terdapat peningkatan pelepasan gonadotropin releasing hormone $(\mathrm{GnRH})$, sehinggarasioleutinizing hormone/folliclestimulating hormone (LH/FSH) dan testosteron menjadi tinggi. ${ }^{17}$ Secara anatomis, terdapat hubungan erat antara lobus temporal dengan sistem limbik, termasuk amigdala dan hipotalamus yang terlibat dalam regulasi, produksi,
Silveira dkk melaporkan aktivasi asimetris pada daerah hipotalamus hewan coba yang mengalami bangkitan epilepsi setelah dilakukan stimulasi di daerah amigdala sisi kanan. Metode dilakukan dengan melihat protein Fos proto-onkogen yang diekspresikan oleh neuron teraktivasi (Fos immunoreactivity/ Fos-ir). Pada keadaan normal, protein ini jarang terekspresi. Peningkatan ekspresi terhadap protein Fos menunjukan neuron yang teraktivasi (Gambar 1). Peningkatan jumlah neuron Fos-ir lebih terekspresi pada area hipotalamus yang berperan dan terlibat di 
endokrin reproduksi (MPO,VMHvL dan PMV). Hasil ini sesuai dengan hipotesis yang ada bahwa epilepsi temporolimbik memiliki peran penting pada fungsi reproduksi dan terdapat lateralitas yang membedakan bangkitan epilepsi pada sisi berbeda akan memiliki gejala yang berbeda. ${ }^{2,19}$

Walaupun telah banyak pembuktian baik pada hewan coba maupun manusia, pertanyaan apakah permasalahan endokrin reproduksi berhubungan dengan jenis epilepsinya, ataukah lebih sering terjadi pasien dengan bangkitan fokal atau umum, masih belum dapat disimpulkan. Hal ini mungkin dikarenakan pada beberapa hormon memiliki lokasi reseptor yang berbeda-beda, seperti yang dilaporkan oleh Pfaff dkk bahwa hormon steroid seks lebih sering menyebabkan bangkitan epilepsi fokal karena terdapat reseptor hormon tersebut di daerah limbus.

Melihat dekatnya lokasi anatomi antara hipotalamus dengan fokus epileptogenik di daerah temporomesial, hormon prolaktin dilaporkan meningkat pascabangkitan. Peningkatan hormon prolaktin ditemukan pada $88 \%$ bangkitan umum tonik klonik, $78 \%$ fokal kompleks, dan $22 \%$ fokal sederhana. ${ }^{20}$ Lebih jauh lagi, kadar prolaktin dilaporkan akan turun perlahan hingga ke nilai normal setelah bangkitan epilepsi selesai. ${ }^{1}$

\section{Interaksi Hormon dan OAE}

Beberapa OAE merupakan penginduksi enzim sitokrom P450 di hati yang merupakan jalur primer metabolisme hormon steroid seks dan sex hormone binding globulin (SHBG), sehingga dapat menurunkan kadar hormon di dalam tubuh dan mempercepat pembersihan hormon steroid seks dari dalam tubuh manusia. Hal ini menyebabkan perempuan yang mengonsumsi pil kontrasepsi ataupun kontrasepsi hormonal lainnya dapat mengalami ovulasi, sehingga kejadian kehamilan yang tidak direncanakan meningkat. Oleh karena itu, pada perempuan epilepsi yang mengkonsumsi pil kontrasepsi diperlukan pertimbangan pemilihan $\mathrm{OAE}$ yang tidak menginduksi enzim. ${ }^{1}$

Hormon dan OAE memiliki hubungan yang saling memengaruhi. Hampir semua kadar OAE akan semakin rendah pada kehamilan. ${ }^{20}$ Hal ini terjadi karena perubahan hormon steroid seks pada kehamilan, sehingga menyebabkan percepatan pembersihan OAE atau aktivasi jalur glukuronidasi. Sebagai contoh, interaksi lamotrigin (LTG) pada perempuan dengan kontrasepsi hormonal dilaporkan dapat mempercepat pembersihan LTG. Selain itu, 90\% LTG akan dimetabolisme di hati melalui glukuronidasi yang dikatalisasi oleh UDP-glucuronosyltransferase (UGT1A4) yang merupakan isoenzim dari enzim UGT. ${ }^{1}$ OAE yang dimetabolisme melalui glukuronidasi hati tidak hanya LTG, tetapi juga $30-50 \%$ asam valproat (VPA) akan dimetabolisme melalui glukuronidasi di hati. ${ }^{1,20}$

Interaksi OAE bukan hanya terjadi pada hormon steroid seks, melainkan juga pada hormon tiroid. Penelitian oleh Yilmaz dkk dan Strandjord dkk melaporkan penggunaan $\mathrm{OAE}$, selain levetirasetam, dapat meningkatkan TSH dan menurunkan T4. Metaanalisis yang dilakukan oleh Zhang dkk mengenai efek OAE dan kadar tiroid menyimpulkan bahwa karbamazepin, fenitoin, dan VPA dapat memengaruhi kadar hormon tiroid melalui mekanisme yang belum diketahui secara pasti dan masih diperlukan penelitian lebih lanjut untuk mengetahui dampak klinis yang bermakna. ${ }^{21-22}$

Terganggunya fungsi tiroid berpengaruh sampai ke tingkat seluler. Pada pemberian injeksi diazepam setelah 24 jam dapat merubah pengikatan T3 di nukleus dan merubah ekspresi reseptor tiroid. Untungnya, perubahan tersebut dilaporkan bersifat tidak permanen dan akan hilang setelah injeksi dihentikan. ${ }^{21-22}$

\section{Aplikasi Klinis Interaksi Hormon dan Epilepsi}

Hormon yang berkaitan dengan epilepsi dan telah banyak diteliti serta memiliki bukti-bukti ilmiah adalah hormon steroid seks. Hormon tersebut berperan dalam mencetuskan bangkitan epilepsi, dan sebaliknya bangkitan epilepsi dapat mengakibatkan perubahan hormonal. ${ }^{2}$ Salah satu jenis epilepsi yang terbukti dipengaruhi oleh hormon adalah epilepsi katamenial. Pada epilepsi katamenial, selama masa menstruasi, beberapa hari menjelang, atau sesudah menstruasi, terjadi peningkatan bangkitan epilepsi dua kali lebih sering dibandingkan rerata frekuensi bangkitan epilepsi harian. ${ }^{3,23}$ 
Terdapat tiga tipe epilepsi katamenial berdasarkan fluktuasi hormon steroid seks, yaitu perimenstrual, periovulatori, dan fase luteal yang tidak adekuat. Pada tipe perimenstrual dan periovulatori, terjadi peningkatan rasio hormon estradiol/progesteron dan rasio ini menurun pada saat awal dan di tengah dari fase luteal. Hormon progesteron yang memiliki efek antikejang menurun secara cepat pada fase premenstrual. Hormon estrogen meningkat secara drastis pada fase preovulasi. Adapun tipe fase luteal yang tidak adekuat lebih disebabkan oleh tidak ada peningkatan progesteron, yang seharusnya meningkat pada kondisi normal. ${ }^{23}$

Sementara itu, hormon dan OAE juga memiliki hubungan dua arah. Penggunaan kontrasepsi hormonal bersama dengan beberapa OAE penginduksi enzim dapat menurunkan efektivitas kontrasepsi hormonal. Di lain pihak, efektivitas dan konsentrasi OAE tertentu dapat menurun jika diberikan pada perempuan yang menggunakan kontrasepsi, sehingga dapat menyebabkan bangkitan epilepsi. ${ }^{1}$

\section{Terapi Hormonal pada Epilepsi}

Hingga saat ini kontroversi terapi hormonal untuk epilepsi masih terus berlanjut karena belum tersedia bukti-bukti ilmiah yang sistematis. Klomifen atau pil kontrasepsi oral yang menstimulasi ovulasi dilaporkan dapat mengurangi frekuensi kejang. Selain itu, interaksi terapi hormonal dengan OAE juga menjadi pertimbangan dalam setiap pemberiannya. ${ }^{23}$ Saat ini, pemberian analog sintesis dari allopregnanolon, yaitu ganaxolon, telah memasuki fase 2 penelitian dengan pasien spasme infantil, epilepsi katamenial, bangkitan epilepsi fokal refrakter pada orang dewasa, dan sejauh ini memberikan hasil yang positif meskipun belum konklusif. ${ }^{24}$

Pada sindrom West atau spasme infantil, salah satu terapi yang diberikan adalah terapi hormon adrenocorticotrophic (ACTH) atau steroid. Adrenocorticotrophic berperan sebagai neuromodulator dan merupakan neuropeptida yang mungkin memiliki efek antikejang. Selain itu, ACTH juga dapat berinteraksi dengan reseptor steroid yang memengaruhi voltage-dependent calcium channel.
Adrenocorticotrophic juga memiliki andil dalam sintesis dihydrodeoxy-corticosterone (DHDOC) dan tetrahydrodeoxy-corticosteronen (THDOC), keduanya merupakan modulator reseptor GABA-A. ${ }^{25}$

\section{Interaksi Penggunaan Kontrasepsi Hormonal dan OAE}

Estrogen dan progesteron dipengaruhi oleh enzim metabolik di hati. Beberapa OAE juga berperan dalam menginduksi atau menghambat enzim hati tersebut. Fenobarbital, karbamazepin, fenitoin, topiramat, okskarbazepin dimetabolisme oleh enzim CYP3A4 di hati dan dapat menginduksi aktivitas enzim tersebut. Hal ini akan meningkatkan metabolisme estrogen dan progesteron dari hormon kontrasepsi dan menurunkan kadarnya dalam sirkulasi darah hingga $50 \%$. Dengan demikian, efektivitas kontrasepsi menurun. ${ }^{26}$

Selain itu, fenobarbital, fenitoin, dan karbamazepin dapat meningkatkan SHBG sehingga estrogen dan progesteron yang tidak terikat menjadi lebih sedikit. Pada OAE generasi baru yang juga merupakan penginduksi enzim CYP3A4 (misalnya, topiramat dan okskarbazepin), jika dikonsumsi dengan dosis yang tinggi (topiramat $>200 \mathrm{mg} /$ hari), maka tetap dapat mengganggu efektivitas kontrasepsi hormonal, meskipun efeknya tidak sekuat OAE generasi lama. Dari laporan tersebut, American Academy of Neurology merekomendasikan penggunaan oral kontrasepsi dengan dosis yang lebih tinggi, mulai dari estrogen $50 \mu \mathrm{g} .{ }^{1,26}$

Di lain pihak, OAE yang menghambat enzim hati seperti VPA tidak terlalu memengaruhi efektivitas kontrasepsi. Sayangnya, VPA dapat meningkatkan insiden disfungsi endokrin pada perempuan, misalnya sindrom polikistik ovarium.

Akhir-akhir ini, banyak bukti ilmiah yang menunjukan penurunan efektivitas LTG pada perempuan epilepsi yang menggunakan oral kontrasepsi hormonal. Hal ini mungkin disebabkan oleh pengaruh estradiol yang merupakan induktor kuat enzim UDP-glucuronosyltransferase dalam hal meningkatkan asam glukuronik, sehingga eliminasi LTG dapat meningkat hingga $50 \%{ }^{26}$ 


\section{KESIMPULAN}

Banyak penelitian yang telah membuktikan interaksi antara hormon, epilepsi dan OAE. Meskipun demikian, terapi hormon masih belum menjadi suatu tata laksana yang direkomendasikan. Selain itu, hal yang perlu juga diingat adalah perbedaan sifat masing-masing hormon terhadap bangkitan epilepsi. Pemahaman terhadap pengaruh hubungan antara hormon, epilepsi, dan OAE akan membantu klinisi memberikan tatalaksana terbaik pada pasien epilepsi.

\section{DAFTAR PUSTAKA}

1. Pennell PB. Hormonal aspects of epilepsy. Neurol Clin. 2009;27(4):941.

2. Tauboll E, Sveberg L, Svalheim S. Interactions between hormones and epilepsy. Seizure. 2015;28:3-11.

3. Kelompok Studi Epilepsi PERDOSSI. Pedoman tata laksana epilepsi. Surabaya: Airlangga University Press; 2014.

4. Logothetis J, Harner R, Morrell F, Torres F. The role of estrogens in catamenial exacerbation of epilepsy. Neurology.1959;9:352-60.

5. Smith SS, Waterhouse BD, Woodward DJ. Sex steroid effects on extrahypothalamic CNS. I. Estrogen augments neuronal responsiveness to iontophoretically applied glutamate in the cerebellum. Brain Res. 1987;422:40-51

6. Smith SS, Woolley CS. Cellular and molecular effects of steroid hormones on CNS excitability. Cleve Clin J Med. 2004;71(2):4-10.

7. Marcus EM, Watson CW, Goldman PL. Effects of steroids on cerebral electrical activity. Arch Neurol. 1966;15:521-32.

8. Woolley CS. Hormones and epilepsy. Dalam: Schwartzkroin PA, editor. Encyclopedia of basic epilepsy research. UK: Elsevier; 2009: h. 495-501.

9. Patel SI, Pennell PB. Management of epilepsy during pregnancy: an update. The Adv Neurol Disord. 2016; 9(2):118-29.

10. Leranth C, Petnehazy O, MacLusky NJ. Gonadal hormones affect spine synaptic density in the CA1 hippocampal subfield of male rats. J Neurosci. 2003;23:1588-92.

11. Leranth C, Hajszan T, MacLusky NJ. Androgens increase spine synapse density in the CA1 hippocampal subfield of ovariectomized female rats. J Neurosci. 2004;24:495-9.

12. Tamijani SM, Karimi B, Amini E, Golpich M, Dargahi L,Ali RA, dkk. Thyroid hormones: Possible roles in epilepsy pathology. Seizure. 2015;31:155-64.

13. Danzer SC, Crooks KR, Lo DC, McNamara JO. Increased expression of brainderived neurotrophic factor induces formation of basal dendrites and axonal branching in dentate granule cells in hippocampal explant cultures. J Neurosci. 2002;22(22):9754-63.

14. Escobar GMd, Obrego'n AJM, Rey DFE. Maternal thyroid hormones early in pregnancy and fetal brain development. Best Pract Res Clin Endocrinol Metab. 2004;18(2):225-48.

15. Schroeder AC, Privalsky ML. Thyroid hormones, t3 and $t 4$, in the brain. Front endocrinol. 2014;5:40.

16. Daniele A, Azzoni A, Bizza A, Rossi A, Gainotti G, Mazza S. Sexual behavior and hemispheric laterality of the focus in the patients with temporal lobe epilepsy. Biol Psych. 1997;42:617-24.

17. Herzog AG, Coleman AE, Jacobs AR, Klein P, Friedman MN, Drislane FW, dkk. Relationship of sexual dysfunction to epilepsy laterality and reproductive hormone levels in women. Epilepsy Behav. 2003;4:407-13.

18. Bauer J. Epilepsy and prolactin in adults: a clinical review. Epilepsy Res.1996;24:1.

19. Silveira DC, Klein P, Ransil BJ, Liu Z, Hori A, Holmes GL, de LaCalle S, Elmquist J, Herzog AG. Lateral asymetry in activation of hypothalamic neurons with unilateral amydaliod seizures. Epilepsia. 2000;41(1):34-41.

20. Pennell PB, Hovinga CA. Antiepileptic drug therapy in pregnancy I: gestation-induced effects on AED pharmacokinetics. Int Rev Neurobiol. 2008;83:227.

21. Lossius MI, Tauboll E, Mowinckel P, Gjerstad L. Reversible effects of antiepileptic drugs on thyroid hormones in men and women with epilepsy: a prospective randomized double-blind withdrawal study. Epilepsy Behav. 2009;16(1):64-8.

22. Zhang Y, Shen C, Lai Q L, Fang GL, Ming WJ, Lu RY, dkk. Effects of antiepileptic drug on thyroid hormones in patients with epilepsy: meta analysis. Seizure. 2016;35:72-9.

23. Herzog AG. Catamenial epilepsy: definition, prevalance, pathophysiology and treatment. Seizure. 2008;17:151-9.

24. Steves SJ, Harden CL. Hormonal therapy for epilepsy. Curr Neurol Neurosci Rep. 2011;11:435-42.

25. Verhelst H, Boon P, Buyse G, Ceulemans B, D'Hooghe, De Meirleir L, dkk. Steroids in intractable childhood epilepsy: clinical experience and review of the literature. Seizure. 2005;14:412-21.

26. Reddy DS. Clinical pharmacokinetic interactions between antiepileptic drugs and hormonal contraceptives. Expert Rev Clin Pharmacol. 2010;3(2):183-92. 